FESIEE

Fundación Emilio Soldevilla de la Economia de la Empresa

\section{Management Letters / Cuadernos de Gestión}

\author{
journal homepage: http://www.ehu.eus/cuadernosdegestion/revista/es/
}

ISSN: 1131-6837 / e-ISSN: 1988-2157

\title{
Trends in the explanatory power of factor-based asset pricing models in determining the cost of capital
}

\author{
Evolución de la capacidad explicativa de los modelos de valoración de activos basados en factores \\ en la determinación del coste de capital
}

\author{
Ana B. Alonso-Conde ${ }^{\star}$ Javier Rojo-Suárez ${ }^{\mathrm{a}}$ \\ a Department of Business Administration. Rey Juan Carlos University. Paseo de los Artilleros s/n, 28032, Madrid (Spain). - javier.rojo@urjc.es - https://orcid.org/0000- \\ 0002-7371-3154
}

* Corresponding author: Department of Business Administration. Rey Juan Carlos University. Paseo de los Artilleros s/n, 28032, Madrid (Spain). - ana.alonso@urjc. es - https://orcid.org/0000-0001-8333-2788

\section{A R T I C L E I N F O}

Received 07 June 2021,

Accepted 18 October 2021

Available online 10 February 2022

DOI: $10.5295 /$ cdg.211521aa

JEL: G12, G15

\section{A B S T R A C T}

The recent research on asset pricing shows that the higher liquidity that results from the globalization of financial markets has significantly reduced the returns tied to many market anomaly-based strategies. However, in general, that research does not evaluate the effects that the mitigation of market anomalies may imply on the performance of the classic asset pricing models. On this basis, in this paper we study to what extent the lower returns provided by market anomaly-based strategies imply better performance of those models. Hence, the main purpose of our study is to compare the performance over time of some of the most prominent asset pricing models, namely, the CAPM and the Fama and French three- and five-factor models, on the European and US equity markets, using return series that cover more than 30 years. Our results show that, although the CAPM is the model with the worst performance in explaining excess returns in all periods both in Europe and US, the model has increased its explanatory power in the recent years principally due to the attenuation of classic market anomalies, such as the size effect or the value effect. Furthermore, our results show that the CAPM correctly prices the three classic Fama and French factors for the years 2006-2021, which explains the best performance of the model for that time interval. Our results have important implications for investment analysis, as well as for determining the cost of capital. Keywords: Cost of Capital, Betas, Market Anomalies, CAPM, Multifactor Models.

\section{R E S U M E N}

Dentro del ámbito de la valoración de activos, investigaciones recientes ponen de manifiesto cómo el incremento de la liquidez de los mercados financieros por razón de la globalización se está traduciendo en una paulatina reducción de los diferenciales de rentabilidad proporcionados por diferentes estrategias basadas en anomalías del mercado. No obstante, tales investigaciones no analizan en general el impacto que dicha reducción tiene sobre el funcionamiento de los modelos clásicos de valoración de activos. Sobre esta base, este trabajo se desarrolla al objeto de analizar en qué medida el proceso de atenuación de las anomalías de mercado se traduce en un incremento de la capacidad explicativa de dichos modelos. Así, el principal propósito de este estudio es realizar una comparativa en el tiempo entre los principales modelos de valoración de activos, concretamente el CAPM y los modelos de tres y cinco factores de Fama y French, en los mercados de acciones europeo y estadounidense, haciendo uso de series de rendimientos de más de 30 años. Los resultados obtenidos muestran que, a pesar de que tanto a nivel europeo como estadounidense y en todos los periodos estudiados, el CAPM es el modelo con un peor comportamiento a la hora de explicar los excesos de rentabilidad, el modelo ve incrementada su capacidad explicativa en los años más recientes debido a la atenuación de anomalías clásicas del mercado, como son el efecto tamaño o el efecto valor. Más aún, nuestros resultados confirman que el CAPM es capaz de valorar correctamente los tres factores clásicos de Fama y French para los años 2006-2021, lo que explica el mejor funcionamiento del modelo para ese intervalo de tiempo. Nuestros resultados tienen importantes implicaciones para la gestión y análisis de inversiones bursátiles, así como para la determinación del coste de capital de las empresas.

Palabras clave: Coste de Capital, Betas, Anomalías de Mercado, CAPM, Modelos Multifactor. 


\section{INTRODUCTION}

The correct determination of the cost of capital is a key element in business management due to its strategic implications in project evaluation. In this sense, although the most widely used model in the determination of the cost of equity is the Capital Asset Pricing Model (CAPM), several problems tied to this model explain its poor performance at the empirical level, as well as the proliferation of multifactor models designed to mitigate these problems. On this basis, the aim of this paper is to analyze to what extent the normal functioning of the market, and more specifically the significant increases experienced in recent decades in traded volumes and liquidity in financial markets, has led to changes over time in the empirical performance of the CAPM, as well as the main multifactor asset pricing models.

Two key elements substantiate this study. First, while the poor empirical performance of the CAPM is partly explained by the presence of different market anomalies leading to abnormally high returns, recent research shows how the increase in trading volumes in recent years has significantly reduced the return spreads of such strategies (Mashruwala et al. 2006; Green et al. 2011; Chordia et al. 2014; McLean and Pontiff 2016), and especially that referred to as the value effect, i.e. the fact that stocks of companies with a high book value to market value ratio (hereafter $\mathrm{BE} / \mathrm{ME}$ ratio) provide abnormally high returns. However, it is important to note that, although the aforementioned studies reflect a significant attenuation in numerous market anomalies, such studies do not carry out empirical validation of the CAPM or the Fama and French models, which highlights the relevance of the present study. In this context, Bornholt (2013) notes that, if market anomalies tend to disappear in stock markets, the CAPM could experience a resurgence in its explanatory power.

Secondly, the poor empirical performance of the CAPM is additionally explained by the important differences between the conditional and non-conditional moments that result from stock market returns, which, rather than behaving as independent and identically distributed (i.i.d.) variables, require the use of time-varying coefficients for their adequate specification, as highlighted by the Hansen and Richard (1987) critique. As a direct consequence from this fact, asset pricing models that are typically used in a non-conditional form, such as the CAPM or the multifactor models proposed by Fama and French (Fama and French 1993, 2015), are susceptible to exhibit important shifts in their performance over time, which, together with the aforementioned attenuation of part of the market anomalies documented by the literature, justifies the convenience of studying the performance of linear asset pricing models over time and across different geographical areas.

On this basis, in our research we conduct a study, both for the European and the US equity markets, to evaluate the performance of the CAPM, the three-factor model of Fama and French (1993) (hereafter FF3), and the subsequent revision carried out to include two additional factors (Fama and French 2015) (hereafter FF5), for three different time intervals, namely: 1990-2005, 2006-2021, and 1990-2021, thus extending the time interval used by other recent studies on the area, such as Fama and French
(2017). Using the multiple linear regression method, we analyze and determine the relationship between the factors proposed by each of the models and the expected returns for the defined periods. For evaluation purposes, we compare the average returns of the 25 classic Fama and French portfolios, formed by the size and $\mathrm{BE} / \mathrm{ME}$ ratio of the stocks, and the fitted returns provided by each of the models under analysis. Our estimation procedure explicitly distinguishes two steps: (i) first, for each portfolio we run a time-series regression of excess returns on factors in order to determine beta coefficients, and (ii) second, we run a cross-sectional regression of mean returns on betas to determine market risk prices.

Accordingly, our study contributes to the current body of knowledge in the area of asset pricing, as it examines the explanatory power of the CAPM and other factor models in different time intervals, which capture the significant increases in trading levels experienced in recent years in the financial markets, leading to an important mitigation in different market anomalies. Thus, although our research uses updated data to show the lower explanatory power of the CAPM compared to multifactor models, it also reflects a trend of the CAPM towards a greater explanatory power due to the reduction of market anomalies, such as the size effect or the value effect. In terms of the implications of the study, our results are directly related to the investment decision-making process and the cost of capital of firms.

The remainder of the paper continues in section 2 with a summary of the related literature. The data and methodology used in the research are described in section 3 . Section 4 provides an analysis of the results obtained, and section 5 summarizes our conclusions and suggests directions for future research.

\section{LITERATURE}

The relationship between risk and returns has been a fundamental pillar in the theories of asset pricing postulated in modern financial economics. The CAPM model, proposed by Sharpe (1964) and Lintner (1965), represents the beginning of the asset pricing theory. Six decades later, the CAPM is still widely used, especially to estimate the cost of capital of firms and to evaluate the profitability of asset portfolios. Thus, the CAPM is a robust and intuitive tool for measuring risk and its relationship with expected returns.

However, although classic asset pricing models, with the CAPM as their main exponent, are widely recognized and intensively used in practice for a wide range of purposes, their empirical performance has traditionally been poor. In this regard, an important drawback of the CAPM comes from its most essential element, the market portfolio, which is difficult to represent at an empirical level.

Second, as noted above, for a wide range of market anomalies there is a significant gap between betas and expected returns that, in some cases, even translates into inverse patterns between the two variables. Thus, classic literature on the topic has comprehensively analyzed different puzzles, as is the case of the low beta premium puzzle, the value effect, size effect, price-to- 
earnings (P/E) effect, etc. (Blume and Friend 1973; Black 1972; Basu 1977; Banz 1981; De Bondt and Thaler 1985; Cheol 1994; Hagtvedt 2009). In this sense, the studies by Chan et al. (1991), Fama and French $(1998,2012)$ and Griffin (2002) are remarkable in that they identify different patterns in the size and value of returns on international stocks. Fama and French (1993) argue that, although size and the BE/ME ratio are not themselves state variables, the high average returns of small stocks with a high $\mathrm{BE} / \mathrm{ME}$ ratio produce non-diversifiable risks that the market return cannot capture. The authors explain this statement by the fact that returns of small stocks have a higher covariance with each other than the returns of large stocks, while the returns of stocks with a higher BE/ME ratio (value firms) also have a higher covariance than those with a lower BE/ME ratio (growth firms).

Nevertheless, recent literature on the area continues to study market anomalies in depth. Thus, Asness et al. (2013) find consistent value and momentum effect return premia across eight markets and for diverse asset classes, as well as a strong factor structure among their returns. Their results suggest the presence of common global risks, leading the authors to apply a three-factor asset pricing model. The low beta effect, i.e., the fact most asset pricing models typically underestimate the expected returns of the companies with low betas, constitutes one of the most studied anomalies in the literature. Recently, Elminger (2019) shows that excess returns provided by the strategies based on the low beta anomaly, the value effect and the size effect are quantitative puzzles. Moreover, the author shows that the anomalies associated with the CAPM arise from higher-order moments related to dividends and, consequently, to the distribution of the dividends consistent with the preferences of the representative investor. Hwang et al. (2021) show that the low beta anomaly can be explained by the concept of herding beta, which measures the cross-sectional variation of betas due to changes in the confidence of investors about their market perspectives. Bornholt (2013) analyzes 48 industries in the US and finds that the low beta anomaly has decreased over time.

Finally, an updated full analysis of most market anomalies can be found in Hou et al. (2020). In that study, the authors reproduce the body of results from the literature on market anomalies by compiling a large data database of 452 anomalies, analyzing which of those anomalies are directly replicable. In this regard, the authors conclude that the value and momentum anomalies are easily replicable, as well as the investment and return anomalies. However, the study concludes that a large number of market anomalies are not replicable, meaning that financial markets are more efficient than previously recognized. Furthermore, these findings have traditionally challenged the CAPM and led to exploring different multifactor models.

In contrast to the above studies, there is also evidence that the size effect is disappearing in the US market (Horowitz et al. 2000; Amihud 2002), while in Europe it may even become negative (Baetge et al. 2010). More recently, studies for the UK equity market, such as Rojo et al. (2020), show that the pricing errors delivered by the CAPM have significantly decreased with respect to those in the previous literature, highlighting that time-varying beta models can perform similarly to the Fama-French models.

As it is widely known, Fama and French $(1993,1996)$ propose a three-factor asset pricing model that, additionally to the market risk premium RMRF (i.e. the difference between the market return $\mathrm{RM}$ and the risk-free rate $\mathrm{RF}$ ), the authors add the SMB (Small Minus Big) factor, that is, the return of a diversified portfolio consisting of small stocks minus big stocks, and the HML (High Minus Low) factor, that is, the return of a diversified portfolio consisting of stocks with high minus low BE/ ME ratio. Remarkably, the three-factor model is widely used in empirical research as well as on a practical level. Furthermore, alpha estimates derived from the time series regressions of the model are generally used to measure how quickly stock prices react to certain information (Loughran and Ritter 1995; Mitchell and Stafford 2000). Many practitioners even use the three-factor model as an alternative to the CAPM when estimating the cost of capital of firms.

From a theoretical perspective, the main shortcoming of the three-factor model is that the SMB and HML factors are not directly related to the information that results from the state variables of special hedging concern that affect risk preferences of investors. Moreover, the three-factor model cannot capture the momentum effect (Jegadeesh and Titman 1993), that is, the fact that stocks that have outperformed over the last twelve months tend to perform positively in the following months, and vice versa. In any case, it should be noted that, given that the momentum effect is a short-term anomaly, it is not especially relevant for the estimation of the cost of capital of firms.

Hou et al. (2011) use monthly returns over a sample of 27,000 stocks from 49 countries and a 30 -year time interval to demonstrate that, when a multifactor model includes momentum-based mimicking portfolios and the cash flow-to-price ratio as factors, the model captures satisfactorily the time-series variation of the returns on global equity markets, providing lower pricing errors than classic asset pricing models, such as the CAPM or FF3.

As noted above, the FF5 model (Fama and French 2015) adds two new factors, RMW (Robust Minus Weak) and CMA (Conservative Minus Aggressive) to the classic factors used by FF3. While the RMW factor combines a long and a short position in stocks with high and low operating profitability, respectively, the CMA factor combines a long and a short position in conservative and aggressive investing companies, measuring such investment policy through the asset growth on the balance sheet. It is important to note that the main drawback of the FF5 model is given by the high alphas that result from the portfolios comprising small stocks that invest aggressively, that simultaneously exhibit a low operating profitability — portfolios that covary positively with SMB and negatively with RMW and CMA. The model evaluation procedure used by the authors is the Gibbons, Ross, and Shanken (1989) test (hereafter GRS), which strongly rejects the null that all pricing errors are zero. As a consequence of including the two factors previously described, the explanatory capacity of HML - i.e. the value effect - is smaller as it is redundant with the new factors, that is, the remaining four factors - RMRF, SMB, RMW and CMA - are explanatory of HML returns in time series regressions, meaning that the variation in 
the expected returns of HML is fully captured by the remaining four factors.

\section{DATABASE AND EMPIRICAL ANALYSIS}

In this section we conduct an empirical analysis of the CAPM, FF3 and FF5 models, in order to study the shifts in their performance over time, as well as their explanatory power in the European and US equity markets. The countries included in the European sample are: Austria, Belgium, Denmark, Finland, France, Germany, Great Britain, Greece, Holland, Ireland, Italy, Norway, Portugal, Spain, Sweden and Switzerland. Our data have a monthly periodicity and cover the period from January 1990 to March 2021. To analyze possible temporary differences in the results, we divide the sample into three periods, namely: (i) a first period comprising 1990-2005, (ii) a second period including two periods of economic recession, 2006-2021, and finally (iii) the entire sample, covering 1990-2021.

We have compiled the following data series from the Kenneth R. French online data library (French 2021), for both the European and the US equity markets: (i) the returns of 25 size-BE/ME portfolios, (ii) the three classic FF3 factors (RMRF, SMB and HML), and (iii) the two additional factors RMW and CMA. It should be noted that size-BE/ME portfolios are formed following the methodology proposed by Fama and French (1993), where each June all the stocks traded are allocated into quintiles according to their market capitalization, and in an independent sort to five BE/ME groups. The 25 portfolios under analysis are determined as the intersection of the groups that result from the above classifications. The returns of these portfolios are determined using the average return of the portfolios period by period, weighted by the market capitalization of the stocks in June. Hereafter, we use the standard notation to denote size-BE/ME portfolios according to two digits that range from 1 to 5 , where the first number denotes the size quintile number and the second number the $\mathrm{BE} / \mathrm{ME}$ quintile number. On the other hand, market factors are determined following the methodology described in Fama and French $(1993,2015)$.

We use the multiple linear regression methodology to parameterize the relationship between model factors and expected returns. For that purpose, we the two-pass cross sectional regression procedure to estimate the risk prices $\lambda$ that result from each model. Specifically, we first run 25 time series regressions to estimate beta coefficients $b, s, h, r$ and $c$, and then we determine risk prices as the slope coefficients of the cross-sectional regression of mean returns on betas. The equations that define the cross-sectional models under analysis are as follows:

$$
\begin{aligned}
& \text { CAPM: } E\left(R_{i}\right)-R_{f}=a+b \lambda_{R M R F} \\
& \begin{aligned}
\text { FF3: } E\left(R_{i}\right)-R_{f}= & a+b \lambda_{R M R F}+s \lambda_{S M B}+h \lambda_{H M L} \\
\text { FF5: } E\left(R_{i}\right)-R_{f}= & a+b \lambda_{R M R F}+s \lambda_{S M B}+h \lambda_{H M L} \\
& +r \lambda_{E M W}+c \lambda_{C M A}
\end{aligned}
\end{aligned}
$$

Nomenclature:

$E\left(R_{i}\right)$ : Expected return on asset $i . R_{f}$ Risk-free rate. $b, s, h$, $r$, and $c$ : Slope coefficients that result from the time series regressions. $\lambda$ : Risk prices that result from the cross-sectional regressions. $a$ : Error.

We use the generalized method of moments (GMM) to estimate all models, according to the following vector of constraints:

$$
g_{T}(b)=\left\{\begin{array}{c}
E\left(R_{t}^{e}-a-\beta f_{t}\right) \\
E\left[\left(R_{t}^{e}-a-\beta f_{t}\right) f_{t}\right] \\
E\left(R_{t}^{e}-\beta \lambda\right)
\end{array}\right\}
$$

where $a$ is the vector of intercepts of the time series regressions, and $f_{t}$ is the vector of factors. In order to reproduce the estimates that would result from the two-pass cross-sectional regression using ordinary least squares (OLS) as estimation procedure, we use the following weighting matrix, where $I$ is the identity matrix:

$$
a_{T}=\left(\begin{array}{cc}
I_{2 N} & \\
& \beta^{\prime}
\end{array}\right)
$$

so that:

$$
a_{T} g_{T}(\hat{b})=0_{3 N}
$$

Furthermore, we apply GMM to estimate standard errors, using a spectral density matrix $\mathbf{S}$ without leads and lags, under the assumption of absence of autocorrelation in the errors that result from Equation (4). Specifically, we assume:

$$
S=E\left\{\left[\begin{array}{c}
\left(R_{t}^{e}-a-\beta X_{t}\right) \\
{\left[\left(R_{t}^{e}-a-\beta X_{t}\right) X_{t}\right]} \\
R_{t}^{e}-\beta \lambda
\end{array}\right]\left[\begin{array}{c}
\left(R_{t}^{e}-a-\beta X_{t}\right) \\
{\left[\left(R_{t}^{e}-a-\beta X_{t}\right) X_{t}\right]} \\
R_{t}^{e}-\beta \lambda
\end{array}\right]\right\}
$$

\section{RESULTS}

In this Section we describe the results obtained from our empirical analysis. Accordingly, Table 1 shows the means and standard deviations of the excess returns of the 25 portfolios formed on size and the BE/ME ratio. All results are monthly percentages. Regarding mean returns, there is a clear pattern that suggest that value companies (i.e. those on the right in Table 1, comprising stocks of companies with a high $\mathrm{BE} / \mathrm{ME}$ ratio) outperform growth companies (i.e. those on the left, comprising stocks of companies with a low BE/ME ratio) in most cases. Conversely, the size effect provides mixed results. Specifically, although some $\mathrm{BE} / \mathrm{ME}$ quintiles follow the classic pattern, with portfolios comprising small stocks providing higher returns, and vice versa, other quintiles do not satisfy that relationship or even produce an inverted pattern. 
Table 1

Summary statistics

\begin{tabular}{|c|c|c|c|c|c|c|c|c|c|c|}
\hline \multirow[b]{2}{*}{ Size } & \multicolumn{5}{|c|}{ BE/ME quintiles } & \multicolumn{5}{|c|}{ BE/ME quintiles } \\
\hline & Low & 2 & 3 & 4 & High & Low & 2 & 3 & 4 & High \\
\hline \multicolumn{11}{|c|}{ Panel A: 1990-2005 } \\
\hline \multicolumn{11}{|c|}{ Europe } \\
\hline & \multicolumn{5}{|c|}{ Means } & \multicolumn{5}{|c|}{ Standard deviations } \\
\hline Small & $-0,06$ & 0,30 & 0,46 & 0,70 & 0,99 & 5,46 & 4,96 & 4,48 & 4,08 & 3,93 \\
\hline 2 & $-0,04$ & 0,24 & 0,46 & 0,79 & 0,98 & 5,48 & 4,51 & 4,12 & 3,94 & 4,20 \\
\hline 3 & 0,19 & 0,45 & 0,52 & 0,62 & 0,97 & 5,59 & 4,45 & 4,14 & 4,15 & 4,42 \\
\hline 4 & 0,36 & 0,43 & 0,54 & 0,58 & 0,95 & 5,11 & 4,21 & 4,07 & 4,31 & 4,52 \\
\hline Big & 0,26 & 0,53 & 0,73 & 0,91 & 0,73 & 4,91 & 4,26 & 4,67 & 4,78 & 5,22 \\
\hline \multicolumn{11}{|c|}{ US } \\
\hline & \multicolumn{5}{|c|}{ Means } & \multicolumn{5}{|c|}{ Standard deviations } \\
\hline Small & 0,35 & 1,25 & 1,18 & 1,56 & 1,63 & 8,94 & 7,68 & 5,50 & 5,23 & 5,02 \\
\hline 2 & 0,58 & 0,98 & 1,05 & 1,14 & 1,39 & 7,58 & 5,65 & 4,49 & 4,51 & 5,31 \\
\hline 3 & 0,66 & 0,97 & 0,97 & 1,11 & 1,43 & 7,02 & 5,04 & 4,22 & 4,28 & 4,94 \\
\hline 4 & 0,83 & 0,94 & 1,11 & 1,17 & 1,18 & 6,34 & 4,39 & 4,09 & 4,25 & 5,09 \\
\hline Big & 0,66 & 0,75 & 0,88 & 0,81 & 0,85 & 4,52 & 4,15 & 4,04 & 4,48 & 5,79 \\
\hline \multicolumn{11}{|c|}{ Panel B: 2006-2021 } \\
\hline \multicolumn{11}{|c|}{ Europe } \\
\hline & \multicolumn{5}{|c|}{ Means } & \multicolumn{5}{|c|}{ Standarddeviations } \\
\hline Small & 0,27 & 0,56 & 0,56 & 0,52 & 0,52 & 5,85 & 5,82 & 5,82 & 5,75 & 5,91 \\
\hline 2 & 0,73 & 0,83 & 0,59 & 0,53 & 0,50 & 6,07 & 6,08 & 6,14 & 6,30 & 6,57 \\
\hline 3 & 0,75 & 0,78 & 0,60 & 0,52 & 0,37 & 6,10 & 6,01 & 6,29 & 6,33 & 6,77 \\
\hline 4 & 0,83 & 0,72 & 0,54 & 0,49 & 0,26 & 5,60 & 5,79 & 6,01 & 6,38 & 7,28 \\
\hline Big & 0,61 & 0,56 & 0,39 & 0,29 & 0,27 & 4,59 & 5,12 & 5,86 & 6,07 & 7,86 \\
\hline \multicolumn{11}{|c|}{ US } \\
\hline & \multicolumn{5}{|c|}{ Means } & \multicolumn{5}{|c|}{ Standard deviations } \\
\hline Small & 0,74 & 0,99 & 0,75 & 0,83 & 0,87 & 7,34 & 6,60 & 6,25 & 6,30 & 7,37 \\
\hline 2 & 1,17 & 1,13 & 0,99 & 0,72 & 0,76 & 6,64 & 5,99 & 6,03 & 6,19 & 7,51 \\
\hline 3 & 1,08 & 1,18 & 0,94 & 0,99 & 0,86 & 6,06 & 5,71 & 5,59 & 6,14 & 7,01 \\
\hline 4 & 1,23 & 1,03 & 0,72 & 0,79 & 0,66 & 5,31 & 5,44 & 5,74 & 5,93 & 6,84 \\
\hline Big & 1,12 & 0,84 & 0,81 & 0,27 & 0,75 & 4,39 & 4,20 & 4,58 & 5,74 & 7,01 \\
\hline \multicolumn{11}{|c|}{ Panel C: 1990-2021 } \\
\hline \multicolumn{11}{|c|}{ Europe } \\
\hline & \multicolumn{5}{|c|}{ Means } & & & Ird devi & & \\
\hline Small & 0,15 & 0,49 & 0,56 & 0,67 & 0,82 & 5,61 & 5,37 & 5,14 & 4,94 & 4,97 \\
\hline 2 & 0,40 & 0,60 & 0,59 & 0,73 & 0,81 & 5,73 & 5,32 & 5,18 & 5,21 & 5,45 \\
\hline 3 & 0,51 & 0,67 & 0,62 & 0,63 & 0,76 & 5,81 & 5,23 & 5,26 & 5,29 & 5,66 \\
\hline 4 & 0,63 & 0,63 & 0,61 & 0,62 & 0,70 & 5,30 & 5,00 & 5,08 & 5,39 & 5,98 \\
\hline Big & 0,47 & 0,59 & 0,60 & 0,66 & 0,56 & 4,70 & 4,66 & 5,22 & 5,40 & 6,56 \\
\hline & & & & & US & & & & & \\
\hline & & & Means & & & & & Ird devi & & \\
\hline Small & 0,54 & 1,11 & 0,97 & 1,20 & 1,27 & 8,12 & 7,09 & 5,83 & 5,73 & 6,22 \\
\hline 2 & 0,86 & 1,06 & 1,04 & 0,95 & 1,08 & 7,06 & 5,77 & 5,26 & 5,35 & 6,40 \\
\hline 3 & 0,86 & 1,06 & 0,96 & 1,04 & 1,16 & 6,50 & 5,33 & 4,89 & 5,21 & 5,96 \\
\hline 4 & 1,01 & 0,99 & 0,91 & 0,97 & 0,93 & 5,79 & 4,88 & 4,90 & 5,08 & 5,93 \\
\hline Big & 0,87 & 0,80 & 0,86 & 0,57 & 0,81 & 4,40 & 4,12 & 4,25 & 5,07 & 6,33 \\
\hline
\end{tabular}


Interestingly, by geographic area, US portfolios provide higher expected returns than their European counterparts. In particular, for the period 1990-2005, the premium that results from the difference between the returns of small-value portfolios and large-growth portfolios amounts to $0.73 \%$ for Europe, while it is $0.97 \%$ for the US. On the other hand, while in the period 20062021 that premium amounts to $-0.09 \%$ for Europe and $-0.25 \%$ for the US, in the period 1990-2021 it increases to $0.35 \%$ and $0.4 \%$ for Europe and the US, respectively. In sum, the absolute value of the premium between the returns of small-value portfolios and large-growth portfolios is higher in the US than for Europe in the sub-periods 1990-2005 and 2006-2021, while it is very similar in both geographical areas for the period 1990-2021.

Table 2 shows the means and standard deviations of the factors considered, as well as the correlation matrix between all factors. It is worth noting that the correlation between RMRF and SMB in Europe is negative in the periods 1990-2005 and 1990-2021, while it becomes positive in the period comprising the subprime and coronavirus crises. However, for the US, those correlations are positive for the three periods under study. This is consistent with a larger systematic component in the US than in Europe.

Tables 3-5 show the cross-sectional regression results. For each model in Tables 3-5, the first row shows lambda estimates, the second row the standard errors determined by GMM, and the third row the $t$-statistic. OLS and generalized least squares (GLS) $R^{2}$ statistics are provided for each model, in that order.

Table 3 shows that, for the period 1990-2005, in both the European and the US equity markets, the CAPM delivers the worst results, providing a $R^{2}$ statistics of $0.7 \%$ for Europe and $2 \%$ for the US. On the other hand, the three-factor model performs significantly better, providing a $R^{2}$ statistics of $78.2 \%$ and $58.9 \%$ for Europe and the US, respectively. Moreover, with a $R^{2}$ statistic of $81.8 \%$ and $63.4 \%$ for Europe and the US, respectively, the FF5 model performs better than the FF3 model in both geographical areas. Remarkably, Panel A in Table 3 shows that only HML in FF3 and FF5 and CMA in FF5 are statistically significant, while in Panel B, HML in FF3 and CMA in FF5 are statistically significant.

Table 2

Correlations

\begin{tabular}{|c|c|c|c|c|c|c|c|c|}
\hline & \multicolumn{2}{|c|}{ Factors } & \multicolumn{6}{|c|}{ Correlations } \\
\hline \multicolumn{9}{|c|}{ Panel A: 1990-2005 } \\
\hline \multicolumn{9}{|c|}{ Europe } \\
\hline & Means & Standard deviations & & RMRF & SMB & HML & RMW & CMA \\
\hline RMRF & 0,59 & 4,20 & RMRF & 1,00 & $-0,29$ & $-0,13$ & $-0,23$ & $-0,34$ \\
\hline SMB & $-0,01$ & 2,41 & SMB & $-0,29$ & 1,00 & 0,02 & 0,04 & 0,10 \\
\hline HML & 0,67 & 2,45 & HML & $-0,13$ & 0,02 & 1,00 & $-0,37$ & 0,70 \\
\hline RMW & 0,37 & 1,65 & RMW & $-0,23$ & 0,04 & $-0,37$ & 1,00 & $-0,13$ \\
\hline CMA & 0,27 & 2,13 & CMA & $-0,34$ & 0,10 & 0,70 & $-0,13$ & 1,00 \\
\hline \multicolumn{9}{|c|}{ US } \\
\hline & Means & Standard deviations & & RMRF & SMB & HML & RMW & CMA \\
\hline RMRF & 0,72 & 4,16 & RMRF & 1,00 & 0,10 & $-0,47$ & $-0,47$ & $-0,52$ \\
\hline SMB & 0,31 & 3,50 & SMB & 0,10 & 1,00 & $-0,30$ & $-0,51$ & $-0,09$ \\
\hline HML & 0,53 & 3,27 & HML & $-0,47$ & $-0,30$ & 1,00 & 0,58 & 0,73 \\
\hline RMW & 0,39 & 3,33 & RMW & $-0,47$ & $-0,51$ & 0,58 & 1,00 & 0,30 \\
\hline CMA & 0,34 & 2,47 & CMA & $-0,52$ & $-0,09$ & 0,73 & 0,30 & 1,00 \\
\hline \multicolumn{9}{|c|}{ Panel B: 2006-2021 } \\
\hline \multicolumn{9}{|c|}{ Europe } \\
\hline & Means & Standard deviations & & RMRF & SMB & HML & RMW & CMA \\
\hline RMRF & 0,44 & 5,63 & RMRF & 1,00 & 0,05 & 0,51 & $-0,38$ & $-0,19$ \\
\hline SMB & 0,17 & 1,86 & SMB & 0,05 & 1,00 & 0,01 & $-0,07$ & $-0,23$ \\
\hline HML & $-0,25$ & 2,65 & HML & 0,51 & 0,01 & 1,00 & $-0,78$ & 0,43 \\
\hline RMW & 0,41 & 1,57 & RMW & $-0,38$ & $-0,07$ & $-0,78$ & 1,00 & $-0,36$ \\
\hline CMA & $-0,06$ & 1,44 & CMA & $-0,19$ & $-0,23$ & 0,43 & $-0,36$ & 1,00 \\
\hline \multicolumn{9}{|c|}{ US } \\
\hline & Means & Standard deviations & & RMRF & SMB & HML & RMW & CMA \\
\hline RMRF & 0,88 & 4,62 & RMRF & 1,00 & 0,41 & 0,30 & $-0,25$ & $-0,09$ \\
\hline SMB & 0,09 & 2,60 & SMB & 0,41 & 1,00 & 0,38 & $-0,34$ & 0,11 \\
\hline HML & $-0,33$ & 2,99 & HML & 0,30 & 0,38 & 1,00 & $-0,09$ & 0,48 \\
\hline RMW & 0,26 & 1,69 & RMW & $-0,25$ & $-0,34$ & $-0,09$ & 1,00 & 0,05 \\
\hline CMA & $-0,03$ & 1,55 & CMA & $-0,09$ & 0,11 & 0,48 & 0,05 & 1,00 \\
\hline
\end{tabular}




\begin{tabular}{|c|c|c|c|c|c|c|c|c|}
\hline & \multicolumn{2}{|c|}{ Factors } & \multicolumn{6}{|c|}{ Correlations } \\
\hline \multicolumn{9}{|c|}{ Panel C: 1990-2021 } \\
\hline \multicolumn{9}{|c|}{ Europe } \\
\hline & Means & Standard deviations & & RMRF & SMB & HML & RMW & CMA \\
\hline RMRF & 0,57 & 4,90 & RMRF & 1,00 & $-0,10$ & 0,24 & $-0,31$ & $-0,25$ \\
\hline SMB & 0,09 & 2,14 & SMB & $-0,10$ & 1,00 & 0,01 & $-0,01$ & $-0,02$ \\
\hline HML & 0,24 & 2,55 & HML & 0,24 & 0,01 & 1,00 & $-0,57$ & 0,57 \\
\hline RMW & 0,38 & 1,59 & RMW & $-0,31$ & $-0,01$ & $-0,57$ & 1,00 & $-0,21$ \\
\hline CMA & 0,10 & 1,81 & CMA & $-0,25$ & $-0,02$ & 0,57 & $-0,21$ & 1,00 \\
\hline \multicolumn{9}{|c|}{ US } \\
\hline & Means & Standard deviations & & RMRF & SMB & HML & RMW & CMA \\
\hline RMRF & 0,80 & 4,33 & RMRF & 1,00 & 0,23 & $-0,09$ & $-0,37$ & $-0,34$ \\
\hline SMB & 0,21 & 3,08 & $\mathrm{SMB}$ & 0,23 & 1,00 & $-0,03$ & $-0,45$ & $-0,03$ \\
\hline HML & 0,13 & 3,12 & HML & $-0,09$ & $-0,03$ & 1,00 & 0,36 & 0,63 \\
\hline RMW & 0,33 & 2,62 & RMW & $-0,37$ & $-0,45$ & 0,36 & 1,00 & 0,24 \\
\hline CMA & 0,17 & 2,05 & CMA & $-0,34$ & $-0,03$ & 0,63 & 0,24 & 1,00 \\
\hline
\end{tabular}

Table 3

Regression results (1990-2005)

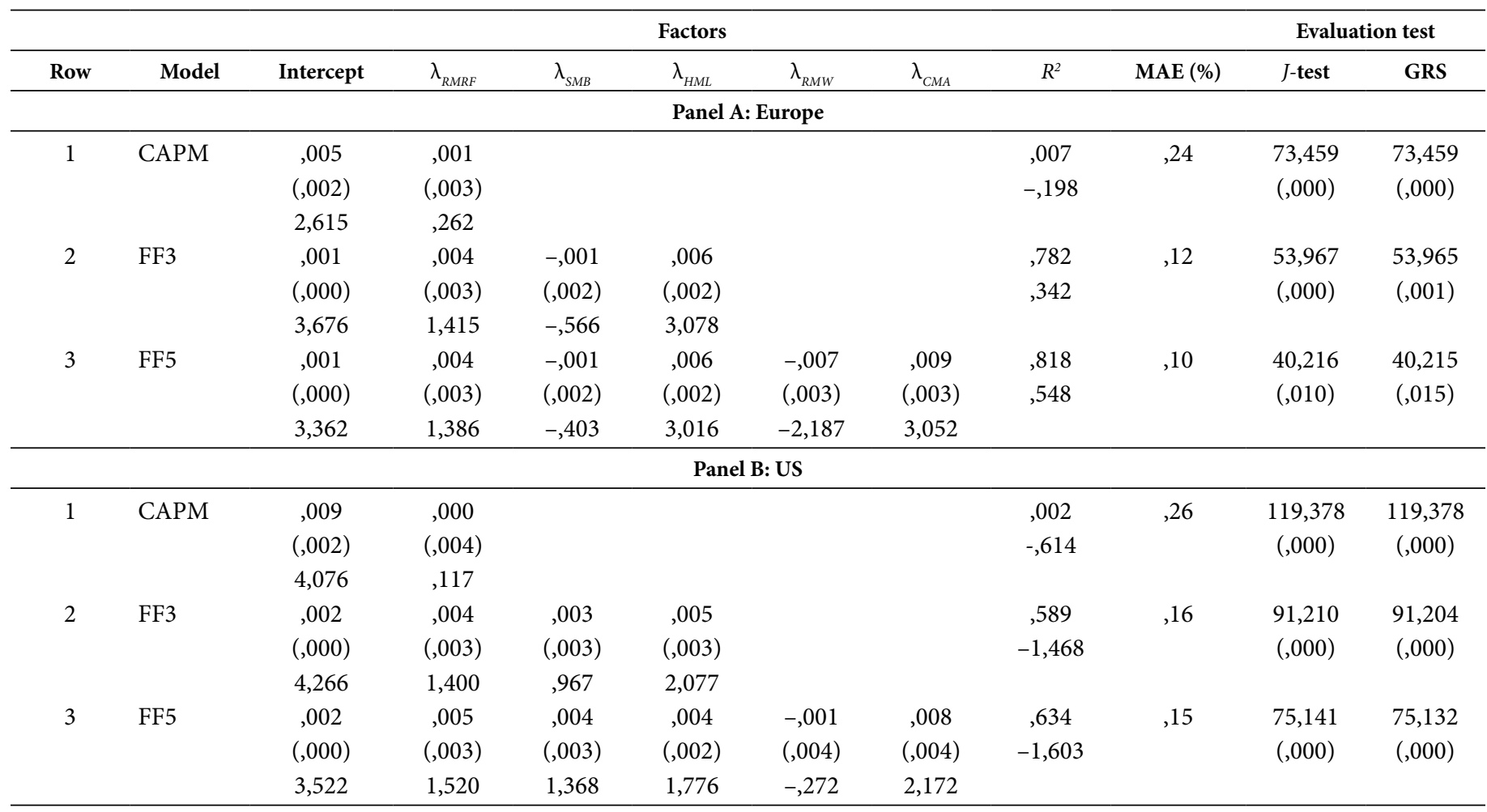

Table 4

Regression Results (2006-2021)

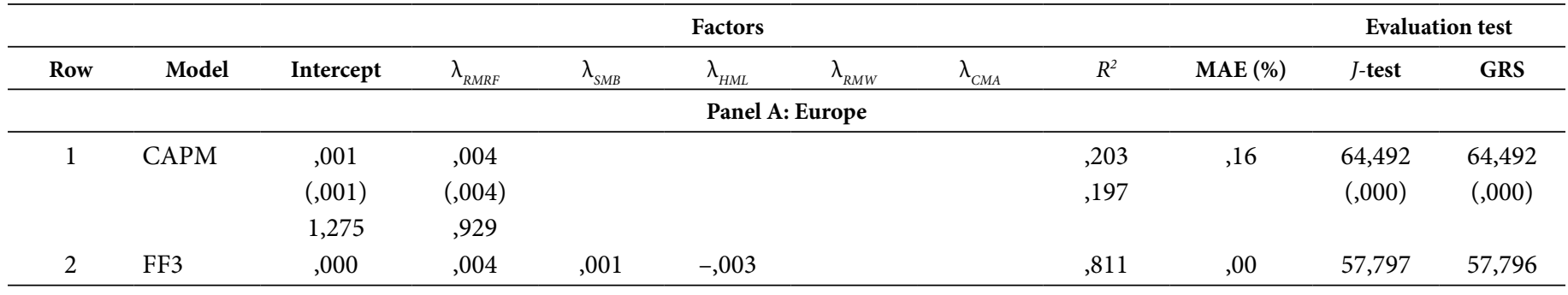




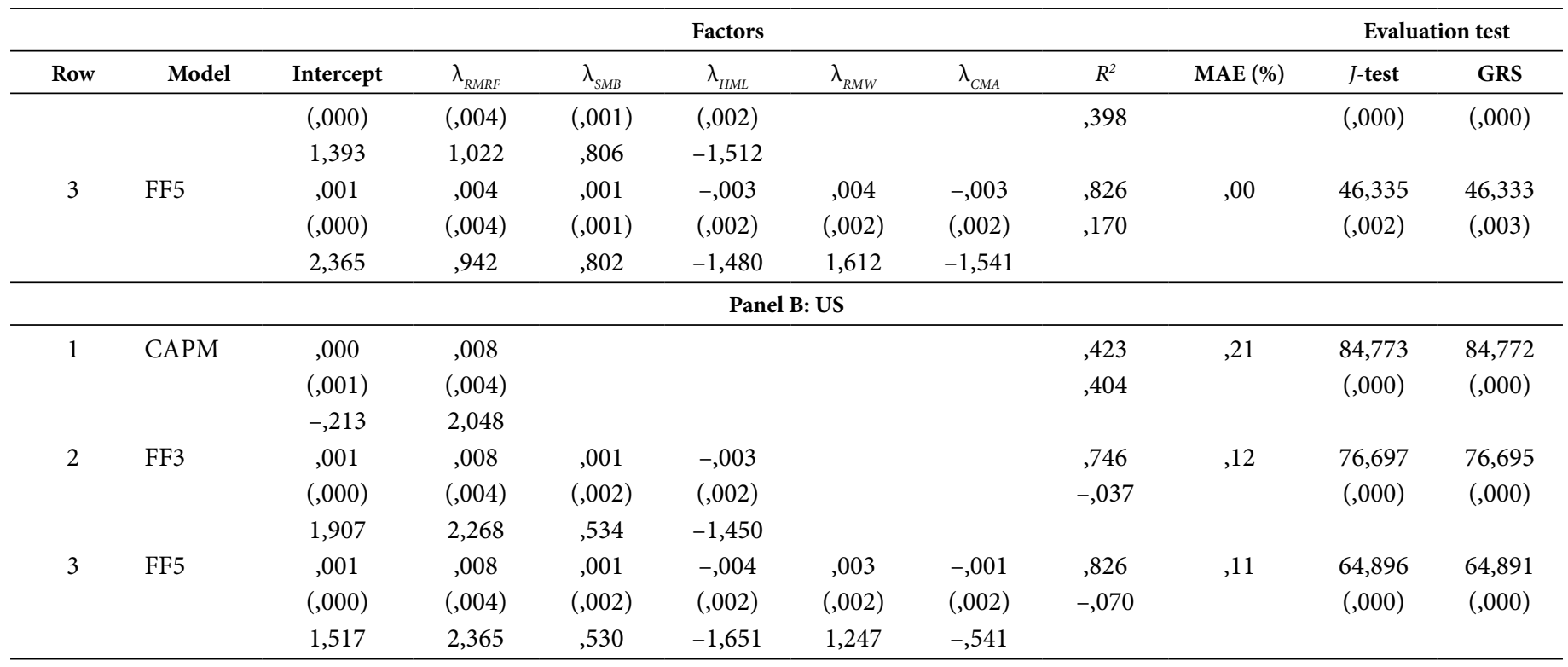

Table 5

Regression Results (1990-2021)

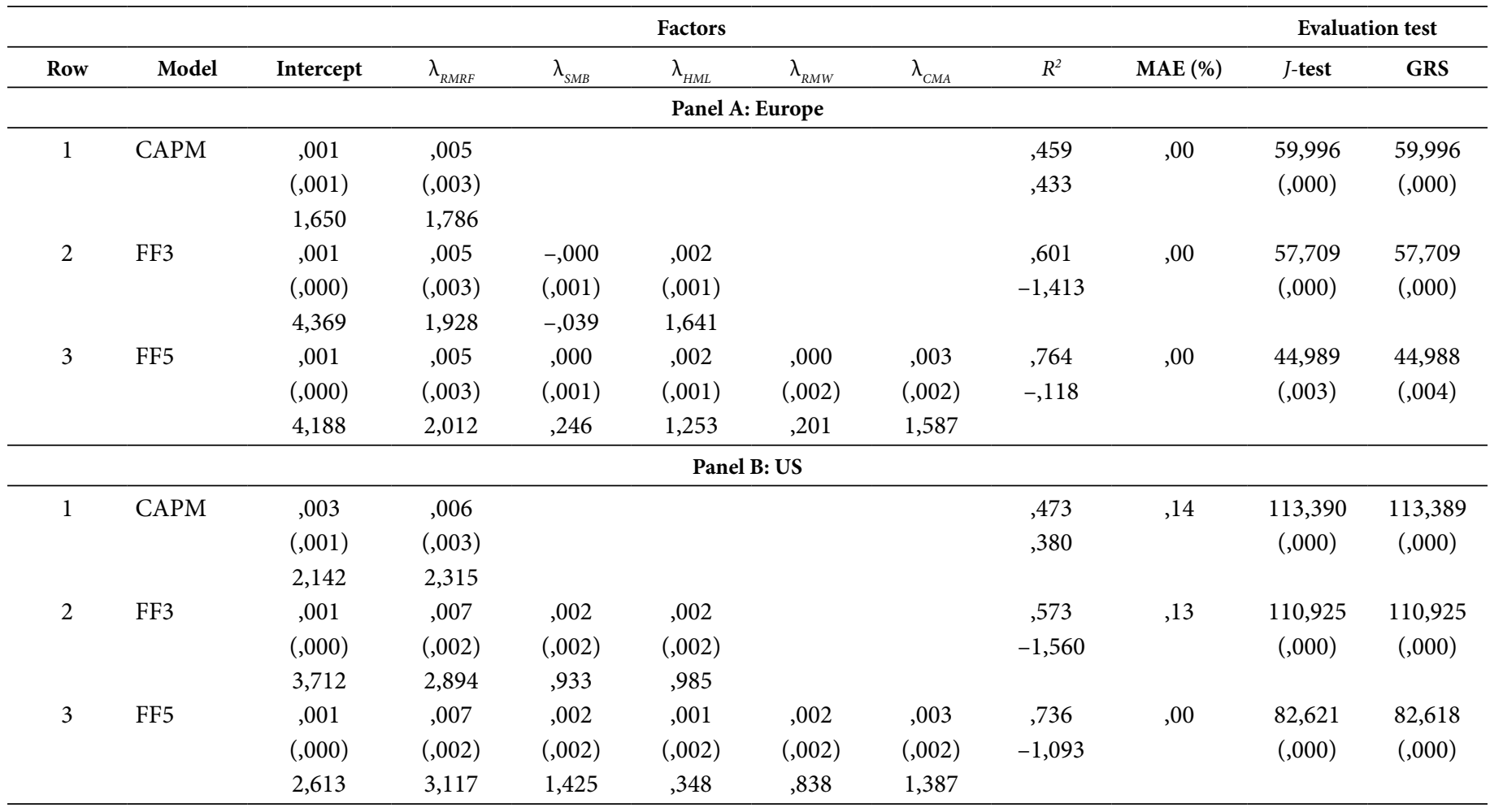

Table 4 shows that, in the period 2006-2021, the $R^{2}$ statistics provided by most models improve in Europe and the US, especially for the CAPM. This fact is consistent with the findings underlined by part of the literature on the topic, which reveals a reduction in the spreads provided by many anomaly-based strategies. Thus, Chordia et al. (2014) find that liquidity stimulus policies and improved trading costs enhance capital market efficiency, which results in a significant reduction in market anomalies in recent years. In this regard, as noted above, Bornholt (2013) shows how market anomalies are not permanent, so that the CAPM can potentially improve its explanatory power over time. Furthermore, the author explains that the low beta anomaly has attenuated in last years, so it is reasonable to suppose that it will disappear in the near future. Similarly, Rojo et al. (2020) find that the increased liquidity that results from the globalization of financial markets has significantly reduced the returns tied to many strategies based on market anomalies for the UK equity market. Consistently, Green et al. (2011) show that hedging returns from anomalies tied to accruals seem to have decrease in the US stock markets. 
It is important to note that, for the period 2006-2021 (see Table 4), FF3 and FF5 models continue to have a high explanatory power with respect to the previous period, with a statistically significant price of risk for RMRF in the US. It is also important to note that lambda coefficients change significantly for the periods 1990-2005 and 2006-2021 (Tables 3 and 4, respectively), which is consistent with time-varying betas, as suggested by Esteban et al. (2015).

Regarding the entire time interval under study, which covers the period 1990-2021, as shown in Table 5, although the CAPM is the model with the lowest $R^{2}$ statistic of the models under analysis,
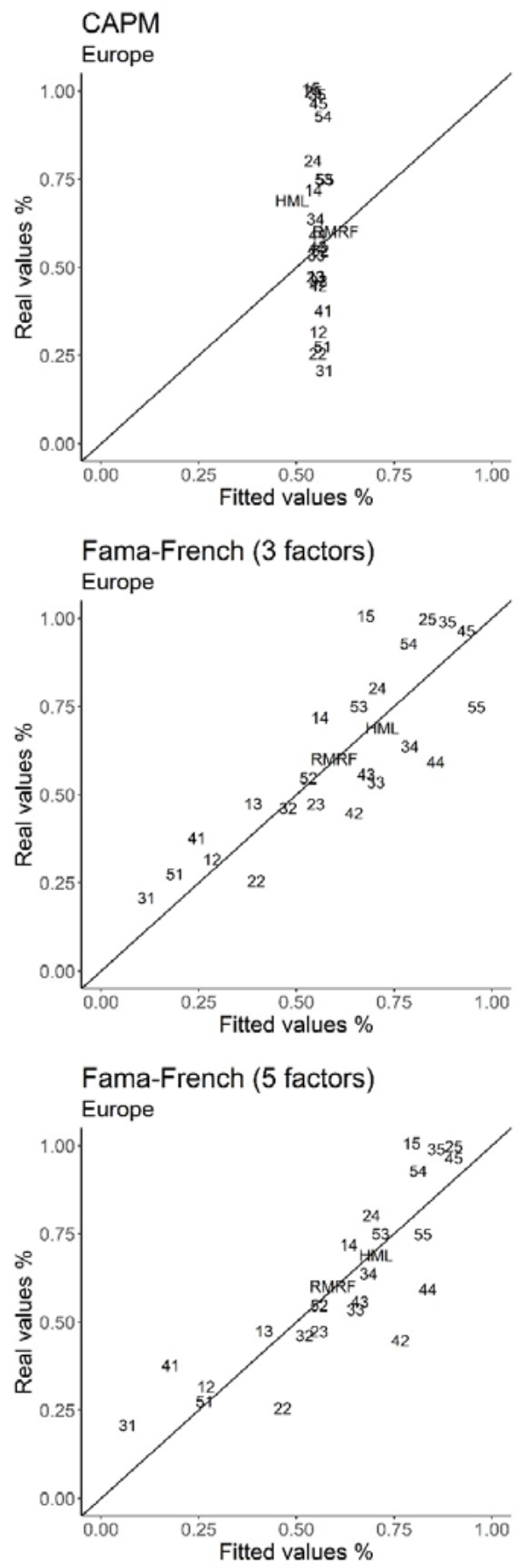

Figure 1

Real values versus fitted values for the period 1990-2005

it delivers a $R^{2}$ statistics of $45.9 \%$ and $47.3 \%$ for Europe and the US, respectively, which are significantly higher values than those shown in Table 3 for the period 1990-2005. Again, FF5 is the model that captures the largest fraction of the variability in portfolio returns, among the models under analysis, with $R^{2}$ statistics of $76.4 \%$ and $73.6 \%$ for Europe and the US, respectively. These results are consistent with those achieved by Horowitz et al. (2000) and Amihud (2002), which suggest that the size effect has disappeared. On the other hand, as is the case in Fama and French (1993, 2015), all models are rejected according to the $J$-test for overidentifying restrictions and the GRS test in all samples.
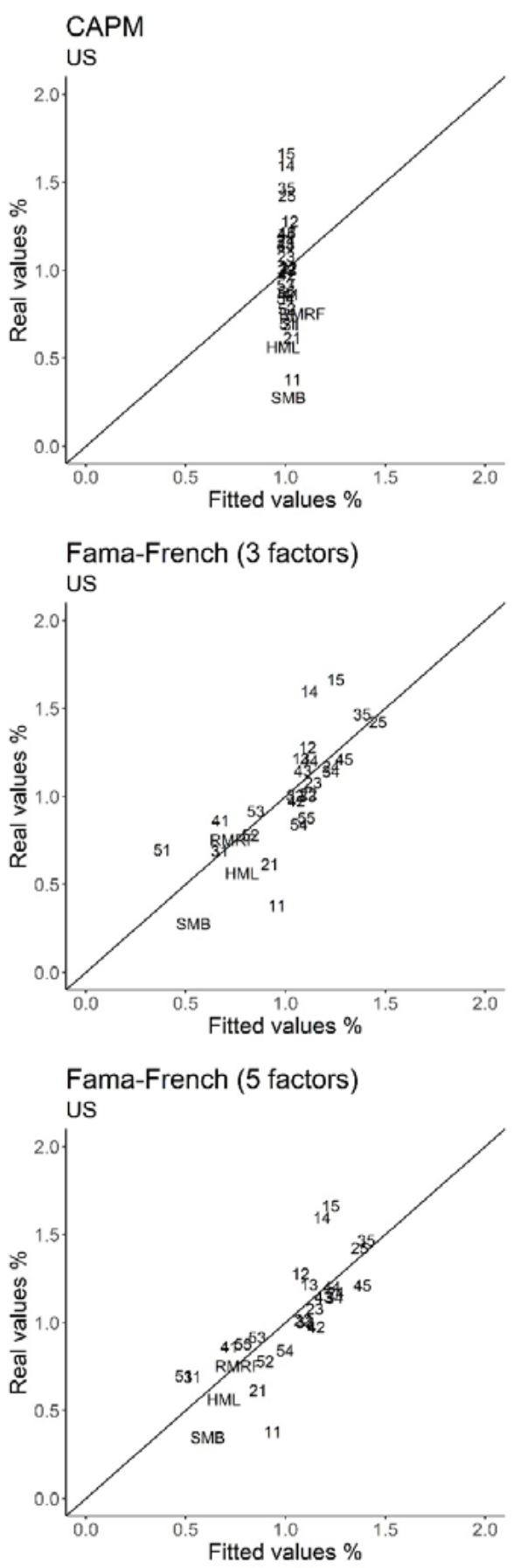

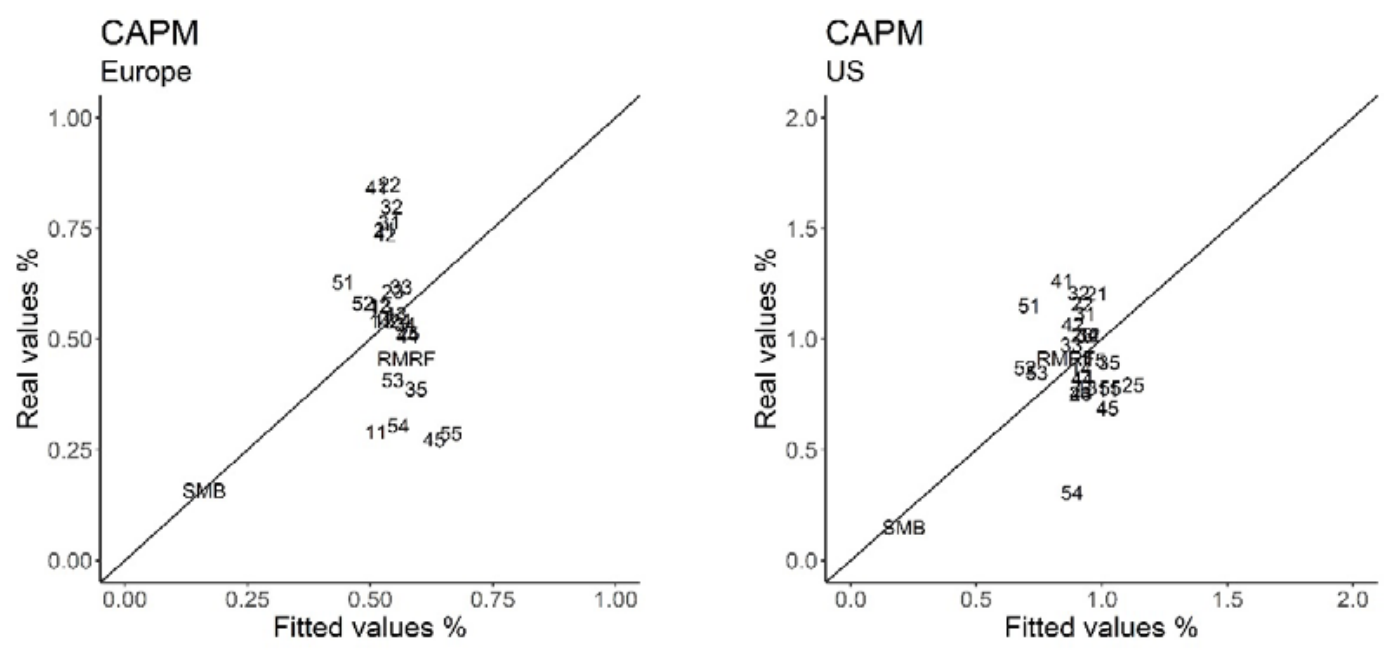

Fama-French (3 factors)
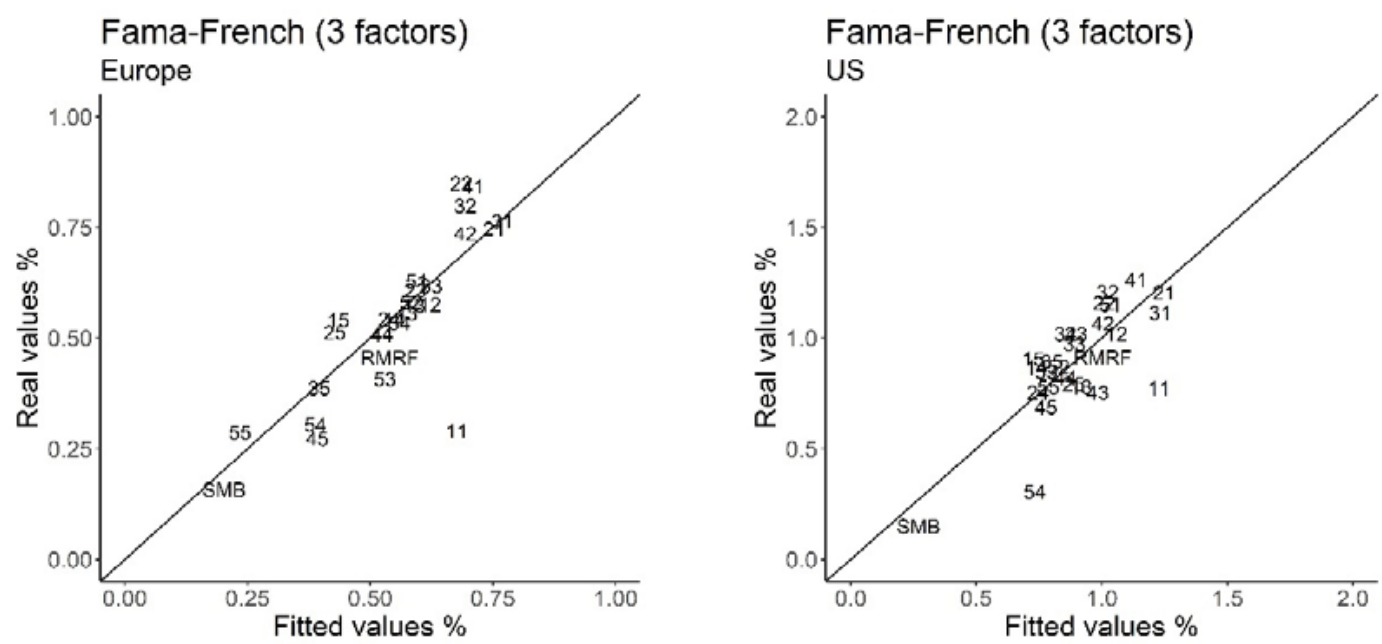

Fama-French (5 factors)
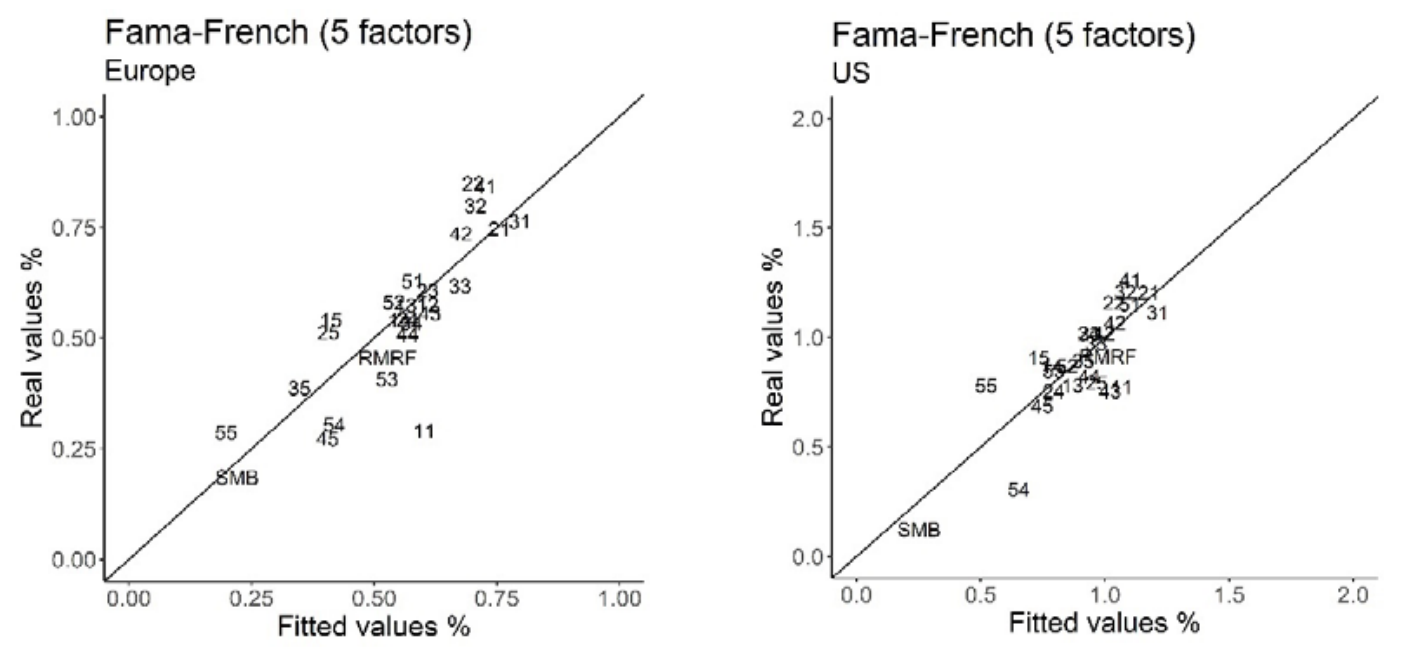

Figure 2

Real values versus fitted values for the period 2006-2021 

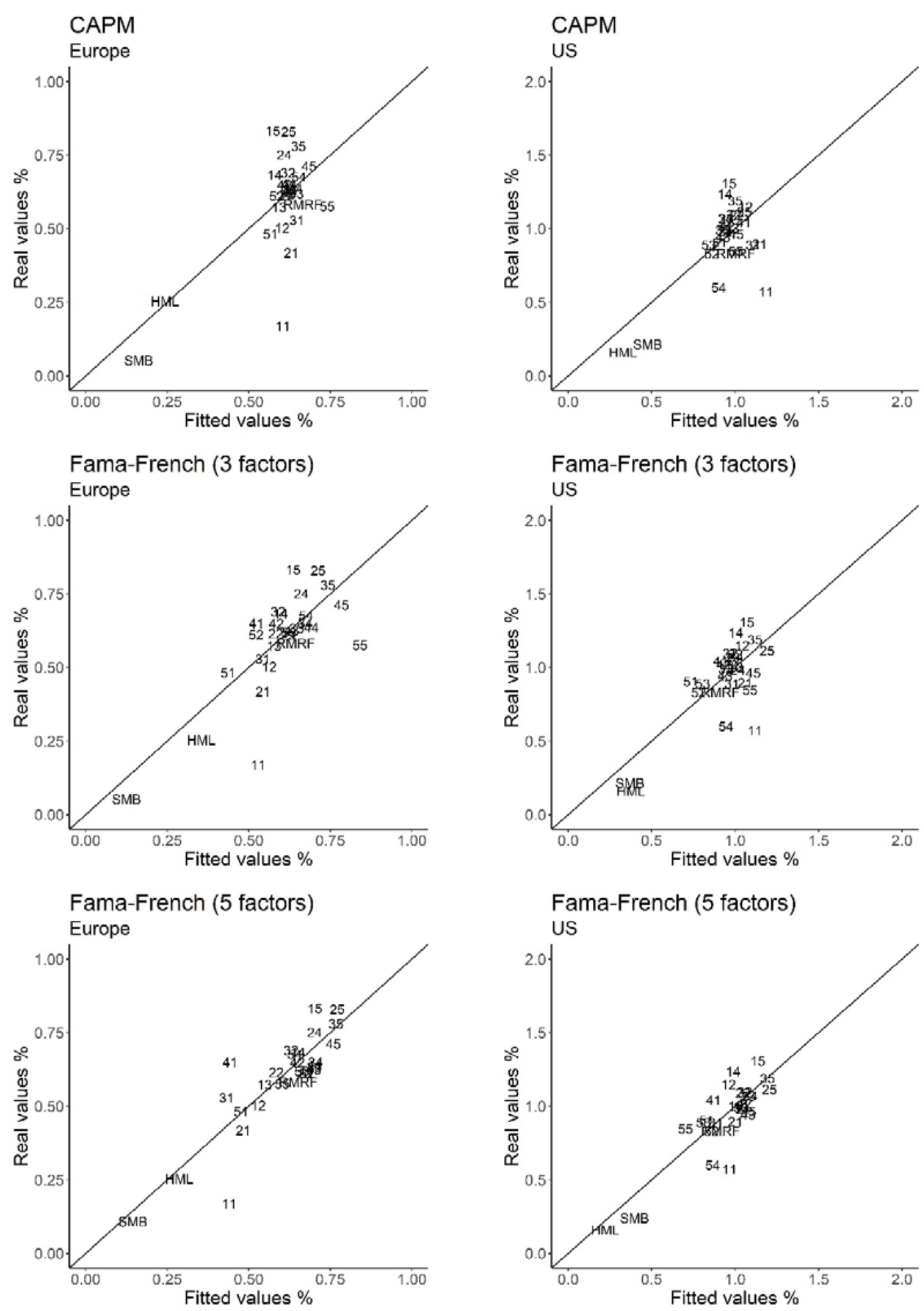

Figure 3

Real values versus fitted values for the period 1990-2021

Finally, Figures 1-3 plot the actual mean returns provided by the portfolios under analysis (vertical axis) and the estimates provided by each model (horizontal axis), so that the smaller the pricing errors, the closer the data points are to the 45-degree axis, and vice versa. Figure 1 shows that, in general, the CAPM provides scattered points that are far from the 45-degree line. Thus, for both Europe and the US, the errors delivered by this model are the largest among the models under study. On the other hand, both FF3 and FF5 fit expected returns significantly better, in most cases. 
Figure 2 shows that, for the CAPM, the portfolios are also very dispersed, but small pricing errors are observed for the FF3 model. As in the previous period, FF3 and FF5 are the best performing models, consistent with the results shown in Table 4. With respect to the period 1990-2021, Figure 3 shows that, despite the high pricing errors of the portfolios under analysis, the CAPM provides low pricing errors for RMRF, SMB and HML, consistent with the results shown in Figure 2, which is consistent with the greater explanatory power of the model for the periods that cover 2006-2021 and 1990-2021.

\section{CONCLUSION}

Using data series for the period from 1990 to 2021, this study analyzes the variation over time of the explanatory power of some of the most prolific asset pricing models of the last decades, in particular, the CAPM and the three- and five-factor models of Fama and French. Given the mixed results provided by the literature on the empirical failures of the CAPM, our study suggests that the use of other explanatory variables, in the context of multifactor asset pricing models, increases the variation in the returns that the model is able to capture, both for Europe and the US, in all the periods under study. Thus, the factors RMW and CMA exhibit a significant explanatory power that allows improving the performance of the three-factor model in our sample. On the other hand, in both markets, the CAPM performs worse compared to multifactor models.

Nevertheless, our results show that the reduction in the spreads provided by different market anomaly-based strategies, particularly the size effect and the value effect, allows the CAPM to improve its performance in Europe and the US. Given that this model is still widely used in practice to estimate the cost of capital of firms, its empirical validation to fit the expected returns of traded firms is crucial, as their actual returns are directly observable.

An additional finding from our study is the validation of a time-varying effect in both model coefficients and their explanatory power over time. Thus, the performance of the models varies over time and depends on the period under study, meaning that the co-movement of stock returns changes over time, consistent with the results reached by Ferreira and Orbe (2018) for Europe. Moreover, the results of the CAPM in recent data (period 2006-2021) suggest that, although the model incurs significant pricing errors for many size-value portfolios, its explanatory power in pricing the three classic Fama French factors is very high. Considering the high factor structure of stock markets worldwide (Lewellen et al. 2010), this fact suggests a progressive increase in the explanatory power of the CAPM in recent years, consistent with the significant reduction in the return spreads provided by different strategies based on market anomalies, as noted by Bornholt (2013) and Chordia et al. (2014).

In any case, as future research, our study should be extended to analyze to what extent the improvement in the explanatory power of the CAPM can be extensive to other cases. In particular, the empirical validation of the CAPM in markets with liquidity levels different from those of the European and the US equity markets, using updated market data for that purpose, is crucial to validate the persistence of our results. Furthermore, the analysis of shifts in the explanatory power of the CAPM in markets for assets other than equities is mandatory, given its direct implications on the assumptions of the market completeness and the representative investor, commonly assumed by most asset pricing models.

\section{ACKNOWLEDGMENTS}

We gratefully acknowledge the funding granted by the European Social Fund and the Education and Research Service of the Madrid regional government, through grant PEJ16/SOC/AI1627.

\section{REFERENCES}

Asness, C.S., Moskowitz, T.J. and Pedersen, L.H., 2013. Value and Momentum Everywhere. The Journal of Finance, 68 (3), 929-985. DOI: 10.1111/jofi.12021

Amihud, Y., 2002. Illiquidity and stock returns: cross-section and time-series effects. Journal of Financial Markets, 5 (1), 31-56. DOI: 10.1016/S1386-4181(01)00024-6

Baetge, J., Kirsch, H.J., Koelen, P. and Schulz, R., 2010. On the Myth of Size Premiums in Corporate Valuation: Some Empirical Evidence from the German Stock Market. Journal of Applied Research in Accounting and Finance, 5 (1), 2-15.

Banz, R.W., 1981. The relationship between return and market value of common stocks. Journal of Financial Economics, 9 (1), 3-18. DOI: 10.1016/0304-405X(81)90018-0

Basu, S., 1977. Investment Performance of Common Stocks in Relation to Their Price-Earnings Ratios: A Test of the Efficient Market Hypothesis. The Journal of Finance, 32 (3), 663-682. DOI: 10.1111/ j.1540-6261.1977.tb01979.x

Black, F., 1972. Capital Market Equilibrium with Restricted Borrowing The Journal of Business, 45 (3), 444-455.

Blume, M.E. and Friend, I., 1973. A New Look at the Capital Asset Pricing Model. The Journal of Finance, 28 (1), 19-33. DOI: 10.1111/ j.1540-6261.1973.tb01342.x

Bornholt, G., 2013. The failure of the capital asset pricing model (CAPM): An update and discussion. Abacus, 49, 36-43. DOI: 10.1111/j.1467-6281.2012.00382.x

Chan, L.K.C., Hamao, Y. and Lakonishok, J., 1991. Fundamentals and Stock Returns in Japan. The Journal of Finance, 46 (5), 1739-1764. DOI: $10.1111 /$ j.1540-6261.1991.tb04642.x

Cheol, S.E., 1994. The Benchmark beta, CAPM, and Pricing Anomalies. Oxford Economic Papers, 46 (2), 330-343. DOI: 10.1093/oxfordjournals.oep.a042132

Chordia, T., Subrahmanyam, A. and Tong, Q., 2014. Have capital market anomalies attenuated in the recent era of high liquidity and trading activity?. Journal of Accounting and Economics, 58, 41-58. DOI: 10.1016/j.jacceco.2014.06.001

DeBondt, W. and Thaler, R., 1985. Does the stock market overreact?. The Journal of Finance, 40, 793-805. DOI: 10.1111/j.1540-6261.1985. tb05004.x

Elmiger, S., 2019. CAPM-anomalies: quantitative puzzles. Economic Theory, 68, 643-647. DOI: 10.1007/s00199-018-1137-5

Esteban, M.V., Ferreira, E. and Orbe-Mandaluniz, S., 2015. Nonparametric methods for estimating and testing for constant betas in asset pricing models. Applied Economics, 47 (25), 2577-2607, DOI:10.108 0/00036846.2015.1005812 
Fama, E.F. and French, K.R., 1993. Common Risk Factors in the Returns On Stocks And Bonds. Journal of Financial Economics, 33, 3-56.

Fama, E.F. and French, K.R., 1996. Multifactor Explanations of Asset Pricing Anomalies. The Journal of Finance, 51 (1), 55-84. DOI: 10.1111/j.1540-6261.1996.tb05202.x

Fama, E.F. and French, K.R., 1998. Value versus Growth: The International Evidence. The Journal of Finance, 53 (6), 1975-1999.

Fama, E.F. and French, K.R., 2012. Size, Value, and momentum in international stock returns. Journal of Financial Economics, 116, 1-22. DOI: $10.1016 /$ j.jfineco.2012.05.011

Fama, E.F. and French, K.R., 2015. A five-factor asset pricing model. Journal of Financial Economics, 116 (1), 1-22. DOI: 10.1016/j.jfineco.2014.10.010

Fama, E.F., and French, K.R., 2017. International tests of a five-factor asset pricing model. Journal of Financial Economics, 123 (3), 441463. DOI: $10.1016 /$ j.jfineco.2016.11.004

Ferreira, E. and Orbe, S., 2018. Why are there time-varying comovements in the European stock market?. The European Journal of Finance, 24 (10), 828-848, DOI: 10.1080/1351847X.2017.1339622

French, K.R., 2021. Current research returns [Base de datos]. Recuperado el 2 de junio de 2021 de https://mba.tuck.dartmouth.edu/pages/ faculty/ken.french/data_library.html

Gibbons, M.R., Ross, S. and Shanken, J., 1989. A Test of the Efficiency of a Given Portfolio. Econometrica, 57 (5), 1121-1152. DOI: $10.2307 / 1913625$

Griffin, J., 2002. Are the Fama and French factor global or country specific?. Review of Financial Studies, 15 (3), 783-803. DOI: 10.1093/ $\mathrm{rfs} / 15.3 .783$

Green, J., Hand, J.R.M. and Soliman, M.T., 2011. Going, going, gone? The apparent demise of the accruals anomaly. Management Science, 57, 797-816. DOI: $10.2139 /$ ssrn. 1501020

Hagtvedt, R., 2009. Stock return dynamics and the CAPM anomalies. Applied Economics Letters, 16 (16), 1593-1596. DOI: $10.1080 / 13504850701582159$

Hansen, L.P. and Richard, S.F., 1987. The Role of Conditioning Information in Deducing Testable Restrictions Implied by Dynamic Asset Pricing Models. Econometrica, 55(3), 587-613. DOI: $10.2307 / 1913601$

Hwang, S., Rubesam, A. and Salmon, M., 2021. Beta herding through overconfidence: A behavioral explanation of the low-beta anomaly. Journal of International Money and Finance, 111, article: 102318. DOI: $10.1016 /$ j.jimonfin.2020.102318
Horowitz, J.L., Loughran, T. and Savin, N.E., 2000. The disappearing size effect. Research in Economics, 54 (1), 83-100. DOI: 10.1006/ reec.1999.0207

Hou, K., Karolyi, G. and Kho, B., 2011. What factors drive global stock returns?. Review of Financial Studies, 24 (8), 2527-2574. DOI: 10.1093/rfs/hhr013

Hou, K., Xue, C. and Zhang, L., 2020. Replicating Anomalies. The Review of Financial Studies, 33 (5), 2019-2133, DOI: 10.1093/rfs/ hhy131

Jegadeesh, N. and Titman, S., 1993. Returns to Buying Winners and Selling Losers: Implications for Stock Market Efficiency. The Journal of Finance, 48 (1), 65-91. DOI: 10.1111/j.1540-6261.1993. tb04702.x

Lewellen, J., Nagel, S. and Shanken, J., 2010. A skeptical appraisal of asset pricing tests. Journal of Financial Economics, 96 (2), 175-194. DOI: 10.1016/j.jfineco.2009.09.001

Lintner, J., 1965. The Valuation of Risk Assets and the Selection of Risky Investments in Stock Portfolios and Capital Budgets. The Review of Economics and Statistics, 47 (1), 13-37. DOI: 10.1016/B978-0-12780850-5.50018-6

Loughran, T. and Ritter, J.R., 1995. The New Issues Puzzle. The Journal of Finance, 50 (1), 23-51. DOI: 10.1111/j.1540-6261.1995.tb05166.x

Mashruwala, C., Rajgopal, S. and Shevlin, T., 2006. Why is the accrual anomaly not arbitraged away? The role of idiosyncratic risk and transaction costs. Journal of Accounting and Economics, 42(1), 3-33. DOI: $10.1016 /$ j.jacceco.2006.04.004

McLean, R. D. and Pontiff, J., 2016. Does academic research destroy stock return predictability? Journal of Finance, 71(1), 5-32. DOI: 10.1111/jofi. 12365

Mitchell, M.L. and Stafford, E., 2000. Managerial Decisions and LongTerm Stock Price Performance. The Journal of Business, 73(3), 287329. DOI: $10.1086 / 209645$

Rojo-Suárez, J., Alonso-Conde, A.B. and Ferrero-Pozo, R., 2020. Liquidity, time-varying betas and anomalies: Is the high trading activity enhancing the validity of the CAPM in the UK equity market? International Journal of Finance \& Economics, 1-16. DOI: 10.1002/ ijfe. 2136

Shanken, J., 1992. On the Estimation of Beta-Pricing Models. The Review of Financial Studies, 5 (1), 1-33. DOI: 10.1093/rfs/5.1.1

Sharpe, W.F., 1964. Capital Asset Prices: A Theory of Market Equilibrium under Conditions of Risk. The Journal of Finance, 19 (3), 425442. DOI: $10.1111 /$ j.1540-6261.1964.tb02865.x 
